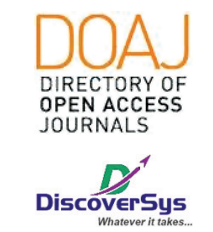

Published by DiscoverSys

\section{Hubungan kadar ferritin dengan TSH dan FT4 akibat transfusi berulang pada penderita thalassemia di RSUP Dr. Kariadi, Semarang, Indonesia}

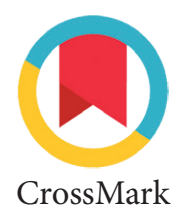

\author{
Ade Delpita, ${ }^{1 *}$ Banundari Rachmawati ${ }^{2}$
}

\section{ABSTRACT}

Background: Thalassemia is a genetic disease that results in abnormal formation of globin chains. Patients with thalassemia led to thyroid dysfunction. Levels of Thyroid Stimulating Hormone (TSH) and Free T4 (FT4) were used to determine the function of the thyroid particularly in a repeated transfusions of thalassemia patients. This study aim to analyze the correlation of ferritin with TSH and FT4 levels due to repeated transfusion in thalassemia patients.

Methods: Retrospective study of analytic observational design, a cross sectional study of 33 thalassemia patients in Kariadi Hospital Semarang during the period from September to Oktober 2018. Correlation analysis with Spearman test. Ferritin levels, TSH an FT4 were used Elisa method. The data were analysed with the SPSS program using the Spearman correlation test

Results: No Correlation analysis between Ferritin levels with TSH levels $(r=-0,087 ; p=0,630)$ and there is weak positive correlation between ferritin levels with FT4 levels $(r=0,390 ; p=0,025)$

Conclusion: There is no correlation between ferritin levels and TSH levels, but there is correlation between ferritin levels and FT4 levels, but Further research is needed to analyze the factors affecting thyroid dysfunction and required additional screening for other thyroid function.
1Program Studi Pendidikan Dokter Spesialis-1 Patologi Klinik, Fakultas Kedokteran, Universitas Diponegoro, Semarang, Indonesia. 2Departemen Patologi Klinik, Fakultas Kedokteran, Universitas Diponegoro, Semarang, Indonesia
Keywords: Thalassemia, Thyroid dysfunction, Ferritin, TSH, FT4.

Cite This Article: Delpita, A., Rachmawati, B. 2019. Hubungan kadar ferritin dengan TSH dan FT4 akibat transfusi berulang pada penderita thalassemia di RSUP Dr. Kariadi, Semarang, Indonesia. Intisari Sains Medis 10(2): 403-407. D0l: 10.15562/ism.v10i2.372

\section{ABSTRAK}

Pendahuluan: Thalassemia merupakan penyakit genetik dimana terjadi kelainan pembentukan rantai globin. Penderita thalassemia dapat terjadi gangguan sistem endokrin, salah satunya disfungsi tiroid. Kadar Thyroid Stimulating Hormone (TSH) dan Free T4 (FT4) dipakai untuk menentukan fungsi tiroid terutama pada transfusi berulang penderita thalassemia Penelitian ini bertujuan menganalisis hubungan ferritin dengan kadar TSH dan FT4 akibat transfusi berulang pada penderita thalassemia.

Metode: Penelitian retrospektif rancangan observasional analitik, pendekatan belah lintang terhadap 33 pasien thalassemia di RSUP Dr. Kariadi Semarang selama periode September - Oktober 2018.
Analisa hubungan menggunakan uji Spearman. Kadar ferritin, TSH dan FT4 diperiksa dengan methoda ELISA. Data di analisis dengan program SPSS versi 21 memakai uji korelasi Spearman.

Hasil: Analisis korelasi tidak terdapat hubungan antara kadar ferritin dengan kadar TSH $(r=-0,087 ; p=0,630)$ dan terdapat hubungan signifikan lemah antara kadar feritin dengan kadar FT4 $(r=0,390$; $p=0,025$ ).

Simpulan: Tidak terdapat hubungan antara kadar ferritin dengan kadar TSH dan terdapat hubungan bermakna antara kadar ferritin dengan kadar FT4. Penelitian lebih lanjut diperlukan untuk menganalisis faktor-faktor yang berpengaruh pada disfungsi tiroid.

Kata kunci: Thalassemia, Disfungsi Tiroid, Ferritin, TSH, FT4

Cite Pasal Ini: Delpita, A., Rachmawati, B. 2019. Hubungan kadar ferritin dengan TSH dan FT4 akibat transfusi berulang pada penderita thalassemia di RSUP Dr. Kariadi, Semarang, Indonesia. Intisari Sains Medis 10(2): 403-407. D0I: 10.15562/ism.v10i2.372

*Korespondensi: Ade Delpita; Program Studi Pendidikan Dokter Spesialis-1 Patologi Klinik, Fakultas Kedokteran, Universitas Diponegoro, Semarang, Indonesia,

adekatin002@gmail.com

Diterima: $16-11-2018$

Disetujui: 04-02-2019

Diterbitkan: 01-08-2019

\section{PENDAHULUAN}

Thalassemia merupakan penyakit genetik yang menyebabkan gangguan sintesis rantai globin, komponen utama molekul hemoglobin $(\mathrm{Hb})$ dan diturunkan secara autosomal sehingga eritrosit cepat lisis. Secara epidemiologi diperkirakan berdasarkan data terakhir dari Badan Organisasi Kesehatan Dunia (WHO) menyebutkan 250 juta penduduk dunia $(4,5 \%)$ membawa genetik thalassemia, dari
250 juta, 80-90 juta di antaranya membawa genetik thalassemia beta. Sementara itu di Indonesia Jumlah penderita thalassemia hingga tahun 2014 tercatat sebanyak 6647 orang dan mengalami kenaikan 45\% dibandingkan tahun 2009., ${ }^{1,2}$

Masalah yang dapat timbul pada penderita thalassemia akibat transfusi darah berulang, anemia kronik, atau akibat penyakit itu sendiri. 
Salah satu masalah penting yang dapat terjadi pada penderita thalassemia adalah gangguan pertumbuhan. ${ }^{2-4}$ Gangguan pertumbuhan dapat disebabkan oleh penurunan kecepatan pertumbuhan, dan hambatan dalam pertumbuhan itu sendiri dinilai dengan mengukur kecepatan pertumbuhan yang dipengaruhi oleh kadar hormon pertumbuhan. ${ }^{5}$

Komplikasi endokrin seringkali muncul pada thalassemia mayor yang memerlukan transfusi secara rutin dan terus menerus, termasuk disfungsi tiroid. Bentuk disfungsi tiroid yang paling sering terjadi adalah hipotiroidisme yang akan mengakibatkan menurunnya produksi hormon tiroid. ${ }^{6-8}$ Hipotiroidisme pada umumnya bermanifestasi saat penderita thalassemia menginjak usia 10 tahun. Hormon tiroid sangat di perlukan untuk metabolisme, pertumbuhan tulang, sintesis protein, dan maturasi jaringan saraf termasuk otak. Hormon tiroid memegang peranan penting dalam pertumbuhan seseorang sehingga bila terjadi kekurangan hormon tiroid, metabolisme dan pertumbuhan tubuh pastinya akan terganggu. ${ }^{15}$ Kelainan endokrin seperti hipotiroidisme terjadi akibat berkurangnya hormon tiroid (T3 dan T4) yang beredar dalam darah. Produk utama dari kelenjar tiroid adalah hormon T4, sedangkan T3 hanya sekitar 20\% dari kelenjar tiroid langsung. ${ }^{16}$

Kadar TSH selain menggambarkan status hipotalamus-hipofisis-tiroid, juga digunakan untuk menentukan fungsi tiroid. Kenaikan atau penurunan kadar hormon tiroid terutama FT4 dapat mengakibatkan pelepasan TSH yang berbanding terbalik sekitar 10 kali. Hal ini menggambarkan bahwa TSH merupakan indikator status tiroid yang sangat sensitif. ${ }^{8,17}$ Latar belakang ini menimbulkan keingintahuan peneliti untuk meneliti sejauh mana hubungan kadar Ferritin dengan kadar TSH dan FT4 akibat transfusi berulang pada penderita thalassemia.

\section{METODE}

Penelitian ini merupakan penelitian retrospektif dengan rancangan observasional analitik, menggunakan pendekatan belah lintang yang dilakukan selama periode September - Oktober 2018 di RSUP Dr. Kariadi Semarang. Penelitian melibatkan 33 pasien dan memenuhi kriteria inklusi. Kriteria inklusi pasien laki-laki atau perempuan umur 1 tahun sampai 26 tahun, pasien thalassemia dengan transfusi berulang, kriteria ekslusi antaralain pasien autoimun, pasien kelainan genetik lainnya, pasien kelainan hepar dan pasien keganasan. Pasien yang memenuhi kriteria inklusi dijelaskan inform concent penelitian dan setelah setuju dilakukan sampling dan pengumpulan sampel penelitian.

Data yang diperoleh dilakukan analisis menggunakan komputer. Uji normalitas data menggunakan Shapiro-Wilk karena besar sampel kurang dari 50. Didapatkan data berdistribusi tidak normal yang kemudian disajikan dalam bentuk mean dan median. Kadar ferritin, TSH dan FT4 diperiksa dengan metoda ELISA menggunakan alat ADVIA Centaur XPT. Hubungan kadar ferritin dengan TSH dan FT4 akibat transfusi berulang pada penderita thalassemia dengan menggunakan Spearman test distribusi data tidak normal. Nilai p bermakna apabila $<0,05$ dan interval kepercayaan $95 \% .{ }^{9}$

\section{HASIL}

Hasil penelitian terhadap penderita thalassemia akibat transfusi berulang di RSUP Dr. Kariadi Semarang didapatkan subjek penelitian yang memenuhi kriteria inklusi dan eksklusi sebanyak 33 subjek. Karakteristik subjek penelitian dapat dilihat pada tabel 1 .

Tabel 1 Karakteristik dasar subjek penelitian

\begin{tabular}{lcc}
\hline Karakteristik & Rata-Rata \pm SB & Median \\
\hline Umur (tahun) & $11,30 \pm 5,16$ & $11(1-26)$ \\
Ferritin (ng/mL) & $1234,55 \pm 215,87$ & $1259(334-1372)$ \\
TSH (mU/L) & $3,35 \pm 1,96$ & $3,34(41-7,63)$ \\
FT4 (mU/L) & $16,83 \pm 3,08$ & $17,05(8,64-22,47)$ \\
\hline
\end{tabular}

TSH: Thyroid-Stimulating Hormone; FT4: Free T4; SB: Simpang baku

Tabel 2 Uji korelasi kadar ferritin dengan TSH dan FT4

\begin{tabular}{lcc}
\hline & \multicolumn{2}{c}{ Ferritin } \\
\cline { 2 - 3 } Variabel & $\mathbf{r}$ & $\mathbf{P}$ \\
\hline TSH & $-0,087$ & 0,630 \\
FT4 & 0,390 & $0,025^{\star}$ \\
\hline
\end{tabular}

TSH: Thyroid-Stimulating Hormone; FT4: Free T4; SB: Simpang baku; Nilai P $<0,05$ menunjukkan berbeda bermakna secara statistik 
Tabel 3 Kadar pada variabel (jumlah subjek)

\begin{tabular}{lccc}
\hline Variabel & Meningkat & Normal & Menurun \\
\hline TSH & 7 & 12 & 14 \\
FT4 & 10 & 23 & - \\
Ferritin & 33 & - & - \\
\hline
\end{tabular}

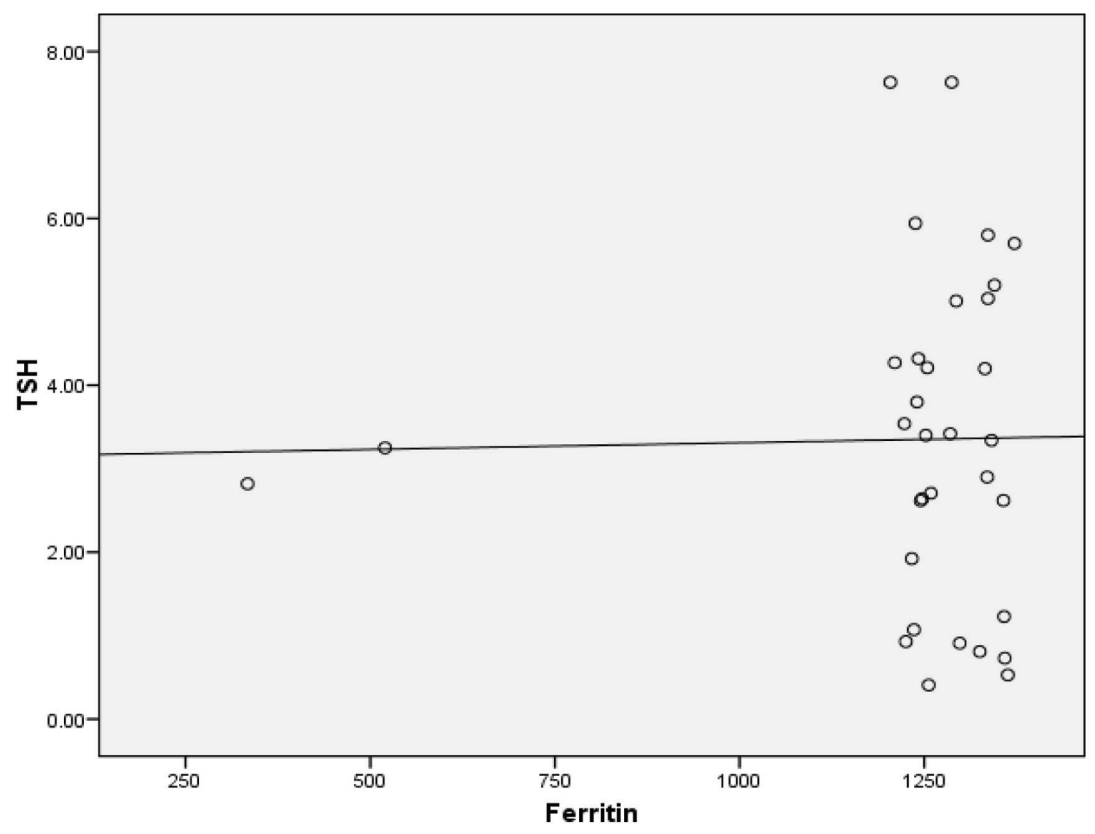

Grafik 1 Korelasi kadar ferritin dengan TSH

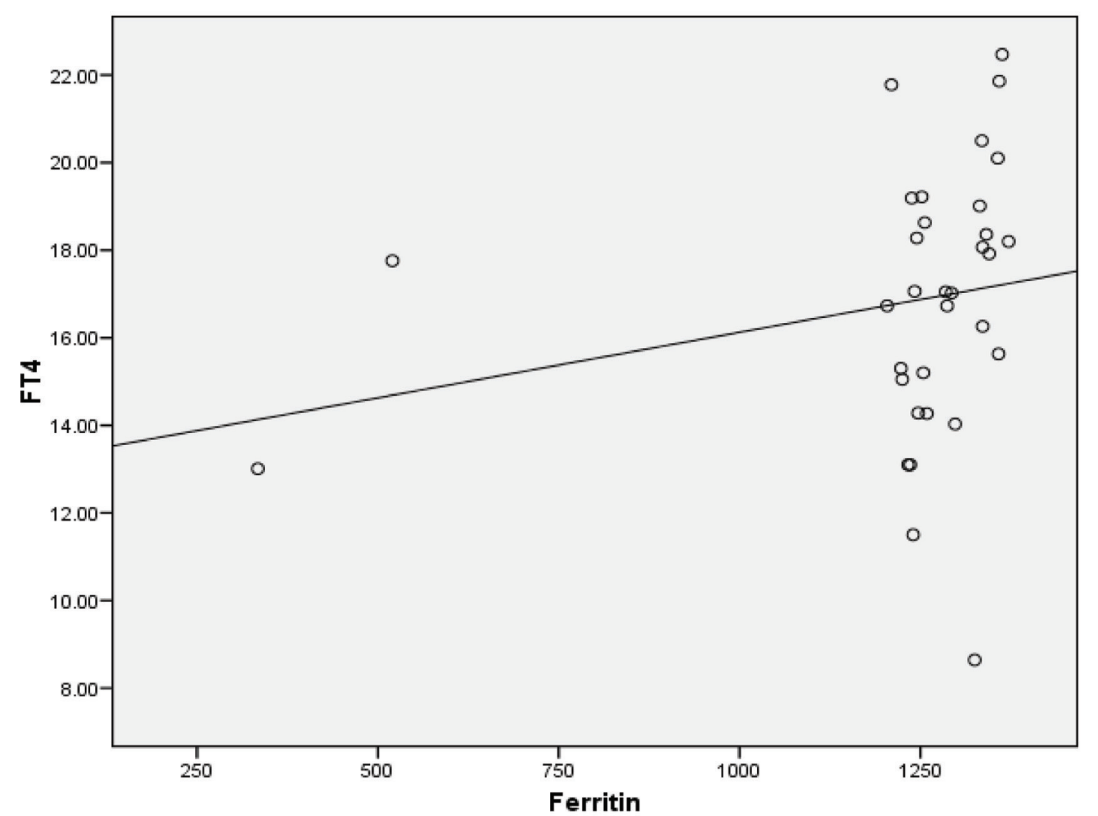

Grafik 2 Korelasi kadar ferritin dengan FT4

Tidak terdapat hubungan yang bermakna antara kadar ferritin dengan kadar TSH $(\mathrm{r}=-0,087$; $\mathrm{p}=0,630$ ) dan terdapat hubungan positif lemah yang bermakna antara kadar ferritin dengan kadar FT4 ( $\mathrm{r}=0,390 ; \mathrm{p}=0,025)$, apabila kadar ferritin meningkat maka FT4 akan meningkat.

\section{PEMBAHASAN}

Data pada penelitian ini diuji dengan analisis korelasi Spearman karena sebaran data tidak normal setelah dilakukan transformasi. Tidak terdapat hubungan yang bermakna antara kadar ferritin dengan kadar TSH dan terdapat hubungan positif lemah yang bermakna antara kadar ferritin dengan kadar FT4. Walaupun kadar TSH tidak didapatkan korelasi dengan kadar ferritin namun kadar TSH pada penderita thalassemia lebih tinggi dari nilai rujukan.

Kadar TSH pada penelitian didapatkan meningkat pada 7 orang dan normal pada 26 orang dengan nilai rujukan kadar TSH 0,5-4,5 U/ml. Kadar FT4 pada penelitian didapatkan meningkat pada 23 orang dan normal pada 10 orang dengan nilai rujukan kadar FT4 10,6-19,0 U/ml.

Beberapa penelitian telah menunjukkan akibat transfusi berulang pada penderita thalassemia terjadi beberapa komplikasi salah satunya adalah kerusakan endokrin, yaitu hipotiroid. Hipotiroid penting diketahui sejak awal dikarenakan hal ini berhubungan dengan gangguan tumbuh kembang, gangguan pada sistem kardiovaskuler, gangguan perkembangan otak pada bayi, dan gangguan metabolisme otak pada bayi dan dewasa..$^{10,11,17}$

Hipotiroid pada pasien thalassemia disebabkan oleh penumpukan besi dan inflamasi. Penimbunan besi pada pasien talasemia dengan transfusi berulang dapat diketahui dengan pengukuran kadar feritin dalam serum. Kadar feritin lebih dari $1000 \mathrm{ng} / \mathrm{mL}$ menandakan adanya kelebihan konsenterasi besi dalam serum dan perlu diberikan terapi kelasi besi. Kadar diatas $2500 \mathrm{ng} / \mathrm{mL}$ dikaitkan dengan peningkatan resiko toksik kardiovaskular dan kematian. ${ }^{10,16,18}$

Keadaan penimbunan besi berlebih juga menimbulkan inflamasi yang dikaitkan dengan peningkatan resiko morbiditas dan mortalitas. Pemberian transfusi darah yang berulang-ulang dapat menimbulkan komplikasi hemosiderosis dan hemokromatosis, yaitu menimbulkan penimbunan zat besi dalam jaringan tubuh (iron overload) sehingga dapat menyebabkan kerusakan organ-organ tubuh seperti hati, limpa, ginjal, jantung, tulang dan pankreas. Kerusakan endokrin seringkali muncul pada thalassemia mayor yang memerlukan transfusi secara rutin dan terus menerus, termasuk disfungsi tiroid. Bentuk disfungsi tiroid yang paling sering terjadi adalah hipotiroidisme yang akan 
mengakibatkan menurunnya produksi hormon tiroid. ${ }^{16,19}$

Pada penelitian ini tidak didapatkan korelasi signifikan antara kadar ferritin dengan kadar TSH $(\mathrm{r}=-0,087 ; \mathrm{p}=0,630)$ dan terdapat korelasi yang positif lemah antara kadar ferritin dengan kadar FT4 $(\mathrm{r}=0,390 ; \mathrm{p}=0,025)$. Beberapa penelitian menyebutkan pada kadar TSH dengan batas atas dari nilai normal (3-5 U/ml) dikategorikan sebagai subclinical hypothyroidism, dimana pada keadaan ini belum tampak gejala klinis hipotiroid, akan tetapi terdapat resiko tinggi untuk menjadi hipotiroid. Kadar TSH dan FT4 yang ditemukan dengan batas atas normal dianjurkan untuk dilakukan pemeriksaan ulang dalam 8-12 minggu. Penelitian ini sesuai dengan penelitian Soumitra Ghosh, dimana terdapat korelasi yang signifikan antara profil thyroid dengan kadar ferritin. Jika hasil pengulangan normal maka tidak diperlukan pemeriksaan lebih lanjut. Dalam keadaan subclinical hypothyroidism berlanjut dilakukan pemeriksaan fungsi tiroid kembali setiap 6 bulan selama 2 tahun pertama, follow-up pengukuran setelah jangka waktu 1 tahun dan setiap 1 kali dalam setahun setelahnya. ${ }^{12,13}$

Hipotiroid pada penderita thalassemia dengan transfusi berulang diakibatkan oleh berbagai mekanisme. Pasien thalassemia terjadi hipoksia disebabkan oleh anemia kronis dan mengakibatkan terjadi kerusakan sel yang berperan dalam kerusakan endokrin. Kerusakan hati yang terjadi pada pasien thalassemia dapat mengakibatkan kerusakan endokrin dikarenakan gangguan metabolisme hormon di dalam hati. ${ }^{14,19,20}$

\section{SIMPULAN}

Pada penelitian ini tidak didapatkan korelasi yang signifikan antara kadar ferritin dengan kadar TSH dan terdapat korelasi positif lemah antara kadar ferritin dengan kadar FT4. Penelitian lebih lanjut diperlukan untuk menganalisis faktor-faktor yang berpengaruh pada disfungsi tiroid, serta jumlah atau kekerapan transfusi darah.

\section{ETIKA PENELITIAN}

Ethical clearance No.002/EC/KEPK-RSDK/2018 diperoleh dari komite etik penelitian kesehatan, Rumah Sakit Umum Pusat Dokter Kariadi.

\section{KONFLIK KEPENTINGAN}

Tidak terdapat konflik kepentingan dalam penulisan laporan hasil penelitian ini.

\section{PENDANAAN}

Penulis bertanggung jawab terhadap pendanaan studi ini tanpa terlibat pada beasiswa, sponsor, maupun sumber pendanaan lainnya.

\section{KONTRIBUSI PENULIS}

Seluruh penulis memiliki kontribusi yang sama dalam penyusunan hingga penyampaian hasil akhir peneltian ini.

\section{DAFTAR PUSTAKA}

1. Lembar S, Dony Y, Aprilia A, Tjahyadi C. Thalassemia. Dalam Buku Saku Hematologi Eritrosit dan kelainannya. Jilid I, 2015;5:155-161.

2. Ehsani MA, Shahgoli E, Rahiminejad MS, Sheighali F, Rashidi A. A new Index for discrimination between iron deficiency anemia and beta thalassemia minor, results in 284 patient. Pakistan J. Biol scien. 2009:12(5): 473 -5.

3. Mosca A, Palani R, Ivaldi G, Galamelle R, Giadano PC.The Role of Haemoglobin A(2) testing in the diagnosis of thalassemia and related haemoglobinopathies." J. Clin Pathol. 2009; 62(1): $13-7$.

4. Ferrara M, Capozzi L, Russo R, Bertocco F, Ferrara I. Reliability OF Red Blood Cell indices and formulas to discriminate between $\beta$ thalassemia trait and iron deficiency in children," Hematology. 2010;15(2): 112-15.

5. Sudoyo AW, setiyohadi B, Alwi I, Simadibrata M, Setiati S. Buku Ajar Ilmu Penyakit Dalam Jilid II Edisi VI. Jakarta: Pusat Penerbitan Departemen Ilmu Penyakit Dalam Fakultas Kedokteran Universitas Indonesia: 2014.

6. Cunningham MJ, Macklin EA, Neufeld EJ, Cohen AR. Complication of $\beta$ - thalassemia major in North America. Blood. 2004; 104 : 34 - 9.

7. Gulati R, Bhatia V, Agarwal SS. Early onset of Endocrine abnormalities in $\beta$ - thalassemia major in a developing country. JPEM. 2006; 13(6): $651-6$.

8. Kal IF. Hiypothyroidisme in thalassemia. General Hospital of Gorinth, 2012. ISBN 978-953-51-0021-8 in Tech Available from. http://www.intechopen.com/books/ hypothiroidisme-in-thalassemia.

9. Priyantiningsih, D. 2010. Pengaruh Deferasirox Terhadap Kadar T4 dan TSH Pada Penderita B-thalassemia Mayor dengan Ferritin yang tinggi. Retrieved from: http://eprints. undip.ac.id/.

10. Dirjen Bina Pelayanan Medik Kementerian Kesehatan RI. Pencegahan Thalassemia (hasil kajian HTA tahun 2009) dipresentasikan pada konversi HTA 16 Juni, Jakarta: Dirjen Bina Pelayanan Medik Kementerian Kesehatan RI. 2010 .

11. Wetherall DJ. The inherited diseases of hemoglobin are an emerging global health burden. Blood. 2010. Juni (3); $115(22): 4331-6$.

12. Nienhuis AW, Nathan DG. Pathophysiology and Clinical Manifestations of the $\beta$ - thalassemia. Cold Spring Harb Prespect Med. 2012; 2(12) : a011726.

13. Fakher R, Bijan K. Better differential diagnosis of iron deficiency anemia from $\beta$ thalassemia trait. Turkish J. Haematol. 2009;26(3): 138-45.

14. Ferdian BA, Rosdiana N, Lubis B. Impact Of Iron therapy on Mentzer Index and red cell distribution width index in primary school children with iron deficiency anemia. Medan: Pediatric Indonesia. 2009; 49(4): 195-196.

15. Sofronescu, A. Thyroid-Stimulating Hormone: Reference Range, interpretation, Collection and Panels. (n.d). [Retrieved January 10 $0^{\text {th }}, 2016$ ) [Available at: www. emedicine.medscape.com/article/2074091-overview). 
16. Hajipour M, Rezaeian S, Abdollahi M, Semati M, et al. Combined Chelation Therapy and Survival of Beta thalassemia Major: A retrospective Cohort Study. Ann Public Health Res. 2015; 2(2): 1020.

17. Soliman AT, Al Yafei F, Al-Naimi L, Almarri N,Sabt A, Yassin M, et al. Longitudinal study on thyroid function in patients with thalassemia major: high incidens of central hypothyroidism by 18 years. Indian J. Endocrinol Metab. 2013; 17(6): 1090-5.

18. Eshragi P, Tamaddoni A, Zarifi K, Mohammadhasani A, Aminzadeh M. Thyroid function in mayor thalassemia patient: Is it related to height and chelation therapy? Caspian J. Intern Med. 2011; 2(1): 189 - 93.
19. Hashemi AS, Golestan M, Arefinia M, Mahmoudabadi F, et al. Hypothyroidism and serum feritin level in patient with mayor b-thalassemia. Iran J. Ped Hematol oncol. 2011; 1(2): 53-6.

20. Gathwala G, Das K, Agrawal N. Thyroid hormone profile in beta thalassemia major children. Indian J. Pediatr 2009;4(2): 20-9

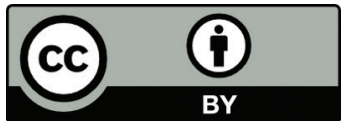

This work is licensed under a Creative Commons Attribution 